\title{
Emendas parlamentares em saúde no contexto do orçamento federal: primeiros resultados
}

\author{
Edgar Caires Gazzola ANDRÉ(1) \\ Leonardo CARNUT ${ }^{(1)}$ \\ (1)Faculdade de Saúde Pública, Universidade de São Paulo - USP, São Paulo, SP, Brasil.
}

Recebido: 28 jan 2019 Aceito: 10 fev 2019

Autor de correspondência: ecga.sp@gmail.com

Conflito de interesses: Os autores declaram não haver nenhum interesse profissional ou pessoal que possa gerar conflito de interesses em relação a este manuscrito.

\section{Resumo}

A partir da Constituição Federal de 1988 foram instituídas diversas normas com o intuito de aproximar o planejamento e o orçamento do Estado. Esta prerrogativa tem como finalidade aproximar o planejado das necessidades das populações e facilitar a execução das ações de acordo com uma lógica de crescimento estrutural das ações da administração pública. É neste sentido que a vinculação da Lei Orçamentária Anual com a Lei de Diretrizes Orçamentárias e o Plano Plurianual, em especial após a promulgação da Lei de Responsabilidade Fiscal 101/2000, elevou o planejamento à posição de destaque na definição dos orçamentos públicos garantindo maior elo entre esses atos administrativos que eram anteriormente fragmentados. No entanto, o que se percebe na prática é a persistência de um planejamento que continua sendo feito de forma não integrada, o que é especialmente danoso uma vez que a dimensão do Brasil e sua heterogeneidade das regiões promove maior complexidade na elaboração de um planejamento que considere diversas especificidades. Assim, um planejamento que vise superar este desafio requer considerar que os investimentos de longo prazo devem ser prioridade na organização do orçamento estatal já que a necessidade premente, especialmente na saúde, é diminuir as desigualdades regionais. Neste bojo, é pertinente lembrar que a iniciativa de apresentação das peças orçamentárias na administração pública é função típica do e prerrogativa exclusiva do Poder Executivo. No entanto o Poder Legislativo também pode apresentar mecanismos para participar do processo orçamentário de forma atípica, sendo o principal deles as chamadas Emendas Parlamentares. Estas são recursos orçamentários reservados para que os parlamentares destinem a determinado estado, município ou entidade uma quantia financeira que podem ser individuais, de bancada, de comissão e da relatoria. Só a título de ilustração, no exercício de 2017 foram empenhados R\$ 13.080.858.366,59, sendo 38,02\% deste valor destinado à Saúde. Em que pese à criteriosa regulação na tentativa de manter essa função original nas mãos do Executivo, as Emendas Parlamentares estiveram no centro de diversos escândalos de corrupção, como o caso dos Anões do Orçamento e Máfia das Sanguessugas, justamente por adequarem-se ao caráter fisiologista do funcionamento político do parlamento bicameral brasileiro, que se consagrou na literatura da ciência política como um presidencialismo de coalizão. Até 2015 as Emendas Parlamentares eram 
autorizativas, ou seja, davam autorização legislativa para o Executivo executar a despesa, mas não obrigava-o. Isso fazia com que diversos autores as considerassem como instrumento de barganha política do Executivo com o Legislativo, conforme explicitado no processo de coalizão. Com a promulgação da Emenda Constitucional (EC) n $86 / 2015$, as emendas passam a ser impositivas, ou seja, o Executivo tem a obrigação de executá-las, salvo em casos de impedimentos técnicos devidamente justificados. No entanto, a utilização das Emendas Parlamentares como instrumento de barganha política segue sendo noticiada, a exemplo da matéria do Estadão de 07 de janeiro de 2018 "Liberação de emendas bate recorde com Temer" sendo recorrentemente associadas à manutenção de currais eleitorais ou como índice dos níveis de corrupção. Além desta mudança, a EC 86 estabeleceu que o montante de 1,2\% da Receita Corrente Líquida seria destinado às emendas e a obrigatoriedade de $50 \%$ das emendas serem destinadas à Ações e Serviços Públicos de Saúde - ASPS, e definiu que este recurso comporia o piso federal de gasto obrigatório em ASPS. Em outras palavras, ao mesmo tempo em que não se ampliou os recursos do setor saúde no que tange ao orçamento direto advindo da seguridade social, parte dele fica de destinação restrita dos parlamentares. Este fato se torna ainda mais significativo quando se considera que, apesar de esta estar em tendência de queda, a participação federal no financiamento do Sistema Único de Saúde - SUS foi da ordem de $43 \%$ em 2017. O orçamento federal para investimentos é bastante dependente das emendas, chegando a mais de $50 \%$ em alguns exercícios fiscais. O caráter irregular da liberação deste recurso, bem como a necessária articulação política com diversos parlamentares para sua obtenção, dificulta a execução de investimentos de longo prazo com objetivo de diminuir iniquidades loco-regionais. Isto demonstra a necessidade das emendas parlamentares serem objeto de rigorosa análise do ponto de vista das necessidades de saúde loco-regionais bem como demonstra a relevância do tema ora em estudo. Objetivo: analisar a literatura científica sobre como as emendas parlamentares influem na alocação de recursos federais na saúde. Método: estudo realizado por meio de Revisão Integrativa do tópico selecionado, iniciando com uma busca por descritores na plataforma Descritores em Ciências da Saúde - DeCS visando identificar aqueles que se vinculariam às duas facetas da questão: Emendas Parlamentares e Alocação de Recursos. Diante da dificuldade de identificar descritores vinculados a Emendas Parlamentares, optouse pela busca de artigos vinculados ao tema de forma exploratória para identificação de quais descritores eram utilizados para a indexação dos mesmos. Assim, foram selecionados os seguintes descritores para busca sistematizada na BIREME: Poder Legislativo; Política de Saúde; Orçamentos; Previdência Social; Financiamento Governamental; "Alocação de Recursos; "Alocação de Recursos para a Atenção à Saúde; Equidade na Alocação de Recursos; e Recursos em Saúde. Em seguida foram utilizadas operações booleanas AND e OR para identificação de estudos que tratem dos dois aspectos levantados, conhecido como técnica do funil. Após diversos cruzamentos ainda haviam estudos 
identificados em busca exploratória que não foram localizados, sendo então incluída a busca por título que contenha "Emendas Parlamentares". Considerações finais: deste modo, a sintaxe final utilizada foi: (mh:("Poder Legislativo" AND "Politica de Saude")) OR (mh:("Poder Legislativo" AND "Orcamentos")) OR (mh:("Politica de Saude" AND "Alocacao de Recursos para a Atencao a Saude" $A N D$ "Previdencia Social")) OR (mh:("Orcamentos" AND "Equidade na Alocacao de Recursos")) $O R$ (mh:("Previdencia Social" $A N D$ "Equidade na Alocacao de Recursos")) $O R$ (mh:((tw:("Previdencia Social" $A N D$ "Recursos em Saude")) $A N D$ (tw:("Financiamento Governamental" AND "Alocacao de Recursos")))) $O R$ (mh:("Financiamento Governamental" $A N D$ "Equidade na Alocacao de Recursos")) OR (tw:(emendas parlamentares)). Assim, foram identificados 47 estudos que passarão por análise de título e resumo por dois pesquisadores para avaliar a pertinência ao tema pesquisado. No entanto, já é possível destacar a quantidade reduzida de estudos publicados sobre o tema, não condizente com a relevância da matéria.

Descritores: Poder Legislativo; Política de Saúde; Orçamentos; Alocação de Recursos; Equidade na Alocação de Recursos. 